Article

\title{
Efficient Sub-1 Minute Analysis of Selected Biomarker Catecholamines by Core-Shell Hydrophilic Interaction Liquid Chromatography (HILIC) with Nanomolar Detection at a Boron-Doped Diamond (BDD) Electrode
}

\author{
Majidah Alsaeedi, Huda Alghamdi, Phyllis E. Hayes, Anna M. Hogan and Jeremy D. Glennon* \\ Innovative Chromatography Group, Irish Separation Science Cluster (ISSC) Ireland, School of Chemistry, \\ The Analytical \& Biological Chemistry Research Facility (ABCRF), University College Cork, Western Road, \\ T12 YN60 Cork, Ireland; 113220101@umail.ucc.ie (M.A.); 113220126@umail.ucc.ie (H.A.); \\ 113222587@umail.ucc.ie (P.E.H.); annamaria.hogan@ucc.ie (A.M.H.) \\ * Correspondence: j.glennon@ucc.ie
}

check for

updates

Citation: Alsaeedi, M.; Alghamdi, H.; Hayes, P.E.; Hogan, A.M.; Glennon, J.D. Efficient Sub-1 Minute Analysis of Selected Biomarker Catecholamines by Core-Shell Hydrophilic Interaction Liquid Chromatography (HILIC) with Nanomolar Detection at a

Boron-Doped Diamond (BDD)

Electrode. Separations 2021, 8, 124 https://doi.org/10.3390/separations 8080124

Academic Editors: Slawomir Neffe, Zygfryd Witkiewicz and

Eduardo Sommella

Received: 23 July 2021

Accepted: 14 August 2021

Published: 18 August 2021

Publisher's Note: MDPI stays neutral with regard to jurisdictional claims in published maps and institutional affiliations.

Copyright: (C) 2021 by the authors Licensee MDPI, Basel, Switzerland. This article is an open access article distributed under the terms and conditions of the Creative Commons Attribution (CC BY) license (https:/ / creativecommons.org/licenses/by/ $4.0 /)$.
Abstract: A rapid, sensitive method for the separation of catecholamine biomarkers (CAs), of importance in traumatic brain injury (TBI) and in Parkinson's disease (PD), has been successfully developed using hydrophilic interaction liquid chromatography (HILIC). Dopamine (DA), epinephrine (EPI), and norepinephrine (NE) are known to be three to fivefold elevated above normal in traumatic brain injury (TBI) patients. HILIC facilitates the rapid and efficient separation of these polar biomarkers, which can be poorly retained by reversed-phase liquid chromatography (RPLC), while electrochemical detection (ECD) at the boron-doped diamond (BDD) electrode provides enhanced nanomolar detection. Three HILIC columns were compared, namely the superficially porous (core-shell) ZHILIC column and the Z-cHILIC and Z-HILIC fully porous columns. The core-shell Z-HILIC showed the highest efficiency with a rapid separation within $60 \mathrm{~s}$. The HILIC method utilizing the core-shell Z-HILIC column was initially optimized for the simultaneous analysis of DA, EPI, and NE using UV detection. The advantages of using the BDD electrode over UV detection were explored, and the improved limits of detection (LODs, $\mathrm{S} / \mathrm{N}=3$ ) measured were 40, 50, and $50 \mathrm{nM}$ for DA, EPI, and NE, respectively. Method validation is reported in terms of the linearity, repeatability, reproducibility, and LODs. Furthermore, the proposed method was successfully applied to the real sample analysis of urinary CAs following phenylboronic acid (PBA) solid phase extraction (SPE) pretreatment.

Keywords: BDD electrode; catecholamines; core-shell particles; HILIC; rapid separation

\section{Introduction}

Catecholamines (CAs) are biogenic amines consisting of a catechol group with an amine side chain, which are synthesized from the amino acid tyrosine [1]. Among the most critical CAs in biological systems are dopamine (DA), epinephrine (EPI), and norepinephrine (NE) [2]. They are released from the adrenal glands and function as neurotransmitters that facilitate intercellular communication within the nervous system [3]. Therefore, they have an essential biological role for many physiological functions, and their levels can be regarded as key biomarkers for several diseases and neurological disorders such as some forms of cancer, Parkinson's disease (PD), and Alzheimer's disease (AD) [2,4,5].

DA is the most abundant CA, and it has a major influence on behavior and physical function. These include learning, motivation, memory [5], movement [6], and heart and kidney function [7]. EPI and NE also play important roles as they control the regulation of the sympathetic nervous system. Based upon their concentration levels, they affect the muscular and cardiovascular function [8]. The overproduction of specific CAs in urine and plasma is utilized for biomarking for types of tumors, such as phaeochromocytomas, neuroblastomas, and ganglioneuromas $[9,10]$. 
Studies have emphasized the association between elevated specific CAs and traumatic brain injury (TBI) [11]. A study by Hamill et al. concluded that these plasma CAs could be utilized as prognostic biomarkers of head injury. Their investigation found that the concentrations of NE and EPI were raised four to fivefold while the DA level increased threefold above normal with TBI patients [11,12]. Further work by Clifton et al. found higher concentrations of NE and DA in the first week after mild-to-severe TBI in 48 patients [13].

An additional CAs-related pathology is Parkinson's disease (PD), as it is caused by the loss of dopaminergic neurons in the substantia nigra in the brain [4]. To date, there is no laboratory test for the early diagnosis of PD [14]. Recently, studies have revealed that peripheral dopaminergic and noradrenergic neuronal degeneration could be an early marker of PD [15-19]. For example, Chekhonin et al. found a positive correlation between PD and a deficiency in urinary and striatum CAs [20]. Consequently, sensitive methods for the analysis of CAs in body fluids, such as in urine, blood, and cerebrospinal fluid, are required to facilitate the early identification of any abnormalities in their levels that are connected to pathological cases.

Various analytical techniques for CAs analysis have been reported. Reverse-phase liquid chromatography (RPLC) using C18 columns hyphenated to different detection systems, including mass spectrometry (MS) [21-23], electrochemical detection (ECD) [24-28], and fluorescence detection [29] has been widely applied. However, due to the non-polar character of $\mathrm{C} 18$ phases and the high polarity of the CAs, derivatization steps, as well as ion pair additives are often considered.

Alternatively, efficient methods for CAs separation based on HILIC, avoiding the need for derivatization or the use of ion pair reagents, have been developed [30-32]. The separation mechanisms in HILIC, including hydrophilic partitioning of polar analytes between the water-enriched stationary phase and the bulk organic mobile phase, hydrogen bonding, ion exchange, and dipole-dipole interactions, provide efficient separation for polar analytes [33]. Different types of HILIC stationary phases have been used in the last 15 years, including bare silica, amide, and zwitterionic bonded phases on polymeric or silica supports.

There is growing recognition of the importance of developing rapid and highly efficient separation and detection methods. Reduced sample and reagent consumption, better sample throughput, and higher productivity are some of the associated advantages. Rapid liquid chromatographic (LC) separations can be achieved using short separation columns, high flow rates with low back pressure, and with a careful choice of particle size, permeability, and temperature. Different types of silica materials have been developed in the last 20 years to enable fast and efficient chromatography, including smaller fully porous particles, monolithic silicas, and superficially porous particles (core-shell) particles.

Their benefits and drawbacks have been reported extensively in the literature [34-38]. The literature also highlights the superiority of core-shell particles in providing rapid separations with a high flow rate and lower backpressure, while offering higher separation efficiency in comparison to traditional fully porous particles of similar dimensions. The effectiveness of utilizing core-shell particles as packing materials in various applications including for the separation of drugs, metabolites, and biomacromolecules [39-41], as well as for the analysis of proteins and peptides [42] has been reported.

CAs are electroactive compounds amenable to detection using ECD. Due to the similar oxidation potential values of CAs, direct ECD is quite challenging, and the need for electrode modification is evident [43]. Coupling sub-minute chromatographic separation to sensitive ECD is now achievable and effective. The BDD electrode has several advantages compared to other available electrodes, such as the glassy carbon electrode (GCE) [44].

The attributes include a wide potential window [45], low background capacitive current [46], high sensitivity, and high resistance to fouling [47,48]. LC coupled with a BDD electrode has been used in many applications, including the detection of chlorophenols in environmental water samples [49], monoamine and purine molecules from the frontal 
cortex and striatal in mouse samples [28], six antidepressant drugs in blood [50], and phenolic compounds in whiskey samples [51].

To the best of our knowledge, this is the first application of HILIC core-shell stationary phases coupled with a BDD electrode for the rapid and sensitive detection of CAs. Amperometric ECD is especially suitable for the sensitive determination of electroactive substances due to its high selectivity, relative simplicity, and low cost. The optimization of the separation and detection conditions, including HILIC column selection, was carried out prior to employing the method for the simultaneous analysis of the selected biomarkers in urine samples.

\section{Materials and Methods}

\subsection{Chemicals and Materials}

LC-MS grade acetonitrile (ACN), ammonium formate, formic acid, sodium dihydrogen phosphate, disodium hydrogen phosphate, trisodium phosphate, dopamine dihydrochloride (DA) (pKa 8.9), epinephrine dihydrochloride (EPI) (pKa 8.6), and norepinephrine (NE) (pKa 8.4) were obtained from Sigma-Aldrich (Dublin, Ireland). All reagents used were analytical grade of the highest purity, and aqueous solutions were prepared in deionized water with a resistivity of $18.2 \mathrm{M} \Omega . \mathrm{cm}$ at $25^{\circ} \mathrm{C}$ (Millipore Purification Pak, Molsheim, France).

An aqueous filter membrane $(0.2 \mu \mathrm{m})$ was purchased from Millipore Ltd., Ireland (Cork, Ireland). Phenylboronic acid cartridges (PBA, $100 \mathrm{mg}$ ) were obtained from Agilent Technologies (Cork, Ireland). Stock solutions were prepared daily at a concentration of $100 \mathrm{mM}$ in $0.1 \%$ formic acid and stored in the dark at $4{ }^{\circ} \mathrm{C}$. The stock solutions were stable for one week and used for further dilution with mobile phase (80:20) $\mathrm{ACN}: \mathrm{H}_{2} \mathrm{O}$ to obtain the desired concentrations of working standards.

For urine sample analysis, urine samples were obtained from two healthy individuals within the research group. A 24-h urine collection was carried out by collecting the urine in a special container over a full 24-h period. The urine samples were kept away from light and stored in the fridge throughout the 24-h period. Lastly, the urine samples were pre-treated using PBA solid phase extraction (SPE) as described elsewhere [32].

Briefly, the PBA cartridge was initially equilibrated with $1 \mathrm{~mL}$ of $80: 20 \mathrm{ACN}: \mathrm{H}_{2} \mathrm{O}$ $(v / v)$ containing $1 \%$ formic acid, and then with $1 \mathrm{~mL}$ of $50 \mathrm{mM}$ phosphate buffer ( $\mathrm{pH} 10)$. A $3 \mathrm{~mL}$ of buffered urine sample (prepared by mixing $1 \mathrm{~mL}$ urine and $2 \mathrm{~mL}$ of phosphate buffer, $\mathrm{pH}$ 8.5) was then loaded to the cartridge. The cartridge was washed with $1 \mathrm{~mL}$ of $(50: 50 \mathrm{v} / \mathrm{v}) \mathrm{ACN}: 10 \mathrm{mM}$ phosphate buffer $\mathrm{pH}$ 8.5. Eventually, the analytes were eluted from the cartridge with $1 \mathrm{~mL}$ of 80:20 ACN: $\mathrm{H}_{2} \mathrm{O}(v / v)$ containing $1 \%$ formic acid and analyzed by HILIC-BDD.

\subsection{Cyclic Voltammetry (CV)}

An electrochemical workstation (CH Instrument, Bee Cave, TX, USA) was used to determine the electrochemical behavior of CAs. An electrochemical cell consisting of silver/silver chloride $(\mathrm{Ag} / \mathrm{AgCl} / 3 \mathrm{M} \mathrm{KCl})$ as a reference electrode (BASi Analytical Instruments, West Layette, IN, USA), BDD as the working electrode (Windsor Scientific, Slough Berkshire, UK), and a Pt wire as a counter electrode (Sigma-Aldrich, Dublin, Ireland) was utilized. Ammonium formate buffer of $\mathrm{pH} 3$ in $85 \%$ ACN was used as the supporting electrolyte for all voltammetric measurements. A stock solution of $100 \mathrm{mM}$ for each CAs was prepared in $0.1 \%$ formic acid.

\subsection{HPLC Instrumentation}

An Agilent 1290 Infinity II UHPLC system (Agilent Technologies, Waghaeusel, Germany) consisting of 1290 Infinity II High Speed Pump (model G7120A), degasser (model G7116B), multi-sampler (model G7167B), and diode array detection (DAD) (G7117B) system was used. Agilent Open Lab CDS workstation software was used for the data analysis. A 
Metrohm $654 \mathrm{pH}$ meter (Metrohm Ltd., Carlow, Ireland) was equipped with a Metrohm Microelectrode (6.0234.100) to give an accurate reading of the $\mathrm{pH}$ up to 3 decimals.

The columns used were Poro-shell (core-shell) Z-HILIC (Length $50 \mathrm{~mm}$, I.D. $2.1 \mathrm{~mm}$, $2.7 \mu \mathrm{m}$ ) (Agilent Technologies, Cork, Ireland), fully porous Z-cHILIC (Length $50 \mathrm{~mm}$, I.D. $2.1 \mathrm{~mm}, 3 \mu \mathrm{m}$ ), and Z-HILIC (Length $50 \mathrm{~mm}$, I.D. $2.1 \mathrm{~mm}, 3.5 \mu \mathrm{m}$ ) from Merck (Darmstadt, Germany). The ECD setting is described in [51]. An Antec Flexcell thin layer flow cell with a cell volume of $0.7 \mu \mathrm{L}$ (Apex Scientific, Co., Kildare, Ireland) was used for ECD. The flow cell consists of a three electrode configuration with a working BDD electrode ( $8 \mathrm{~mm}$ diameter), a HyREF (Pd/H2) reference electrode and carbon-loaded polytetrafluoroethylene (PTFE) counter electrode. A CHI660E electrochemical workstation was used for data analysis $(\mathrm{CH}$ Instrument, Bee Cave, TX, USA).

\subsection{Chromatographic Conditions}

Isocratic separation mode was examined for the separation of the selected biomarker CAs by varying the percentage of $\mathrm{ACN}(75-90 \%)$, the ammonium formate $\mathrm{pH}(3-5)$ and concentration $(10-20 \mathrm{mM})$, and flow rate $(0.5-1.5 \mathrm{~mL} / \mathrm{min})$. The optimum mobile phase composition consisted of $85 \% \mathrm{ACN}(v / v)$ and $10 \mathrm{mM}$ ammonium formate at $\mathrm{pH}$. The selective mobile phase was prepared by mixing $85 \%$ ACN with $66 \mathrm{mM}$ ammonium formate ( $\mathrm{pH} 3$ ) to give $10 \mathrm{mM}$ buffer concentration. The mobile phase was filtered and sonicated for $15 \mathrm{~min}$. Each column was equilibrated with the mobile phase for $20 \mathrm{~min}$ prior to injection. The separation time using the core-shell Z-HILIC column was less than $60 \mathrm{~s}$ with a flow rate of $1.5 \mathrm{~mL} / \mathrm{min}$ and injection volume of $5 \mu \mathrm{L}$. The column temperature was set at $23^{\circ} \mathrm{C}$. LC-UV detection was carried out at $280 \mathrm{~nm}$, while $+1.3 \mathrm{~V}$ in oxidative mode was used in LC-ECD.

\subsection{Validation Procedures}

The statistical analysis was applied in the method validation for the determination of the limit of detection (LOD), linearity, repeatability, accuracy, and precision. LODs were determined utilizing a signal to noise $(\mathrm{S} / \mathrm{N})$ ratio of 3 . The linearity was based on linear regression analysis of the calibration curve between various standard concentrations versus peak areas of each standard (50 to $500 \mu \mathrm{M}$ for LC-UV, and 0.1 to $25 \mu \mathrm{M}$ for LC-BDD)). The intra- and inter-day results were evaluated via triplicate runs of each standard mixture with concentration $500 \mu \mathrm{M}$ for LC-UV and $25 \mu \mathrm{M}$ for LC-BDD. The relative standard deviation $(\mathrm{RSD} \%)$ was obtained to express the precision of the method.

\section{Results and Discussion}

\subsection{Electrochemical Behavior of the CAs Using Cyclic Voltammetry (CV)}

The direct electrochemical responses of DA, EPI, and NE at the bare BDD electrode were recorded in $85 \% \mathrm{ACN}$ with $10 \mathrm{mM}$ ammonium formate buffer at $\mathrm{pH} 3$. In brief, CAs exhibit similar electrochemical behavior as they oxidize to their corresponding o-quinones as illustrated in Scheme 1. CV analysis revealed well-defined oxidation peaks for DA, EPI, and NE on the forward scan at potentials of $+0.82,+0.9$, and $+0.85 \mathrm{~V}$, respectively. The quasi-reversible reactions of DA, EPI, and NE on the BDD electrode were indicated by the corresponding cathodic peaks at $+0.07,-0.27$, and $+0.11 \mathrm{~V}$, respectively, as illustrated in Figure 1.

The electrochemical behavior of the CAs has been extensively reported in the literature [52-55]. Due to the similar redox potentials of the CAs, it is challenging to detect them simultaneously. Several reports have investigated new methods for CA detection based on electrode modification [43,56,57]. However, often due to the complexity, difficulty, and irreproducibility of electrode modification, hyphenation with rapid and robust separation methods is highly effective. 
Dopamine. $\mathrm{R}_{1}=\mathrm{H}, \mathrm{R}_{2}=\mathrm{H}$

Epinephrine. $\mathrm{R}_{1}=\mathrm{OH}, \mathrm{R}_{2}=\mathrm{CH}_{3}$

Norepinephrine. $\mathrm{R}_{1}=\mathrm{OH}, \mathrm{R}_{2}=\mathrm{H}$<smiles>[R2]NC([R])CC1=CC(=O)C(=O)C=C1</smiles>

Scheme 1. Electrochemical oxidation of CAs.
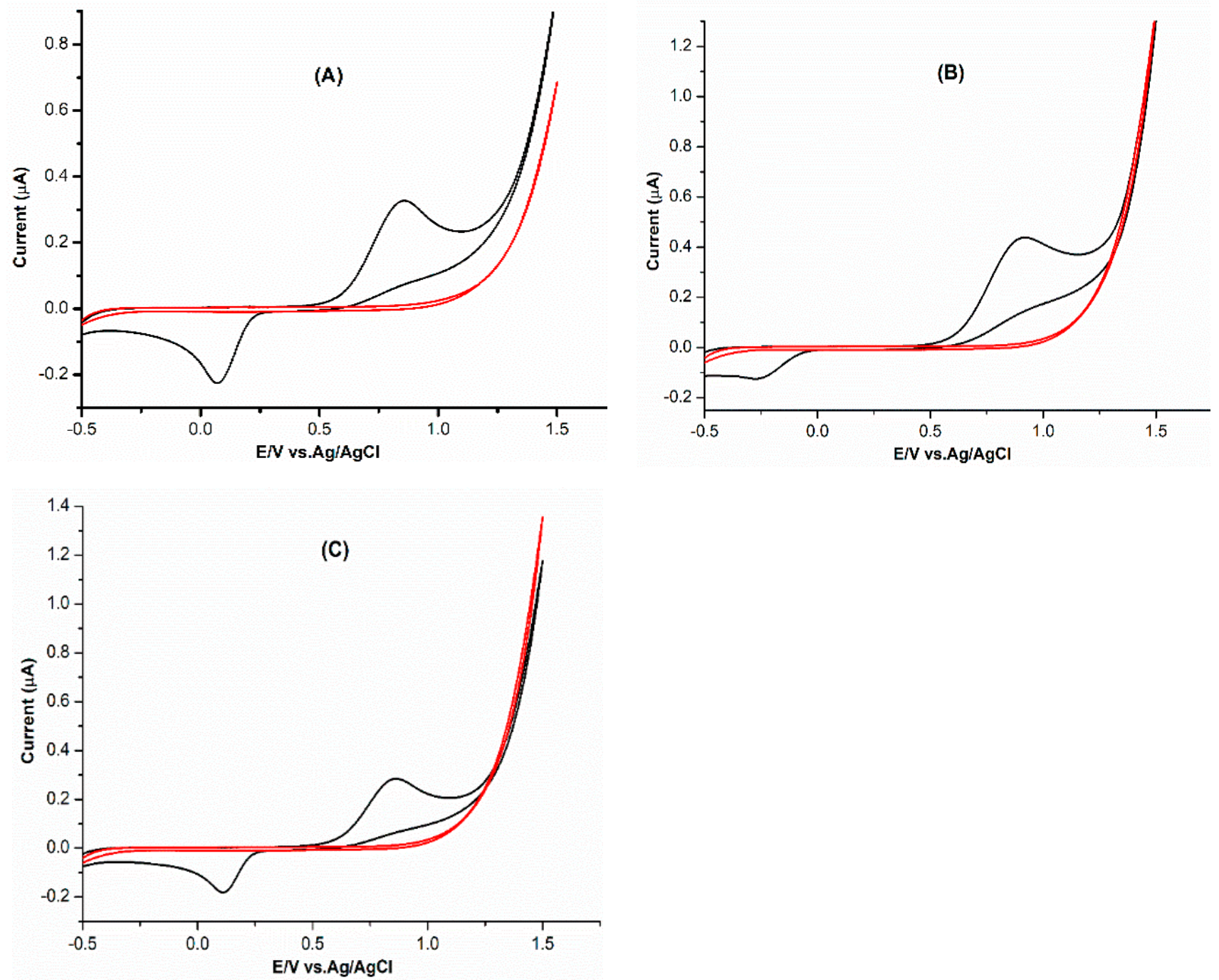

Figure 1. Cyclic voltammograms of CAs in the absence (red line) and presence (black lines) of $100 \mu \mathrm{M}$ each (A) DA, (B) EPI, and (C) NE on the bare BDD electrode vs. $\mathrm{Ag} / \mathrm{AgCl}$. Background electrolytes consist of $10 \mathrm{mM}$ of ammonium formate at $\mathrm{pH} 3.0$ in $85 \%$ ACN with a scan rate of $100 \mathrm{mV} / \mathrm{s}$.

\subsection{Comparison of Zwitterionic HILIC Columns}

Three different commercially available zwitterionic columns were tested for the separation of the CAs. Separation using two fully porous Z-HILIC columns was compared to the core-shell Z-HILIC column under the same separation conditions (Figure 2). The core-shell 
Z-HILIC phase uses a novel zwitterionic stationary phase bonded to a robust hybrid silica particle, while the Z-cHILIC and Z-HILIC fully porous columns contain a zwitterionic phosphorylcholine functional group and sulfobetaine functional group, respectively.
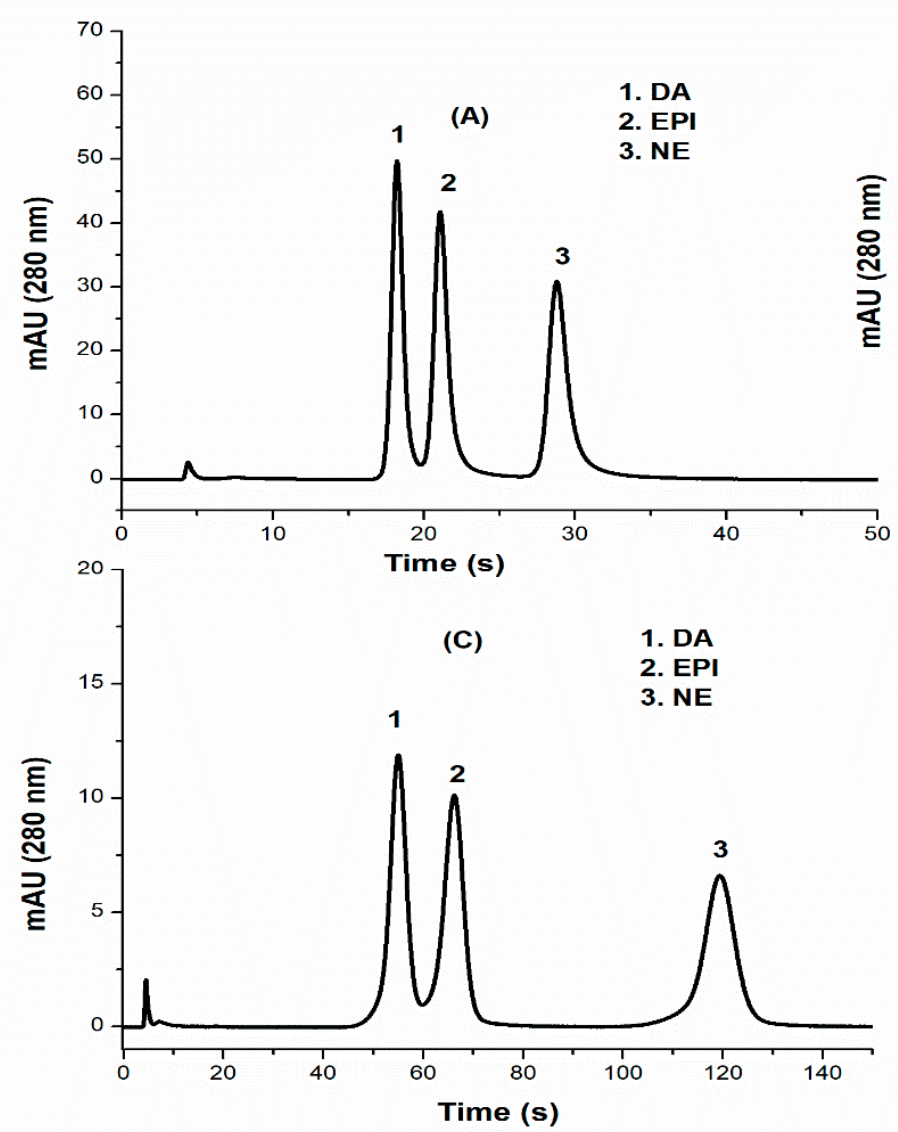

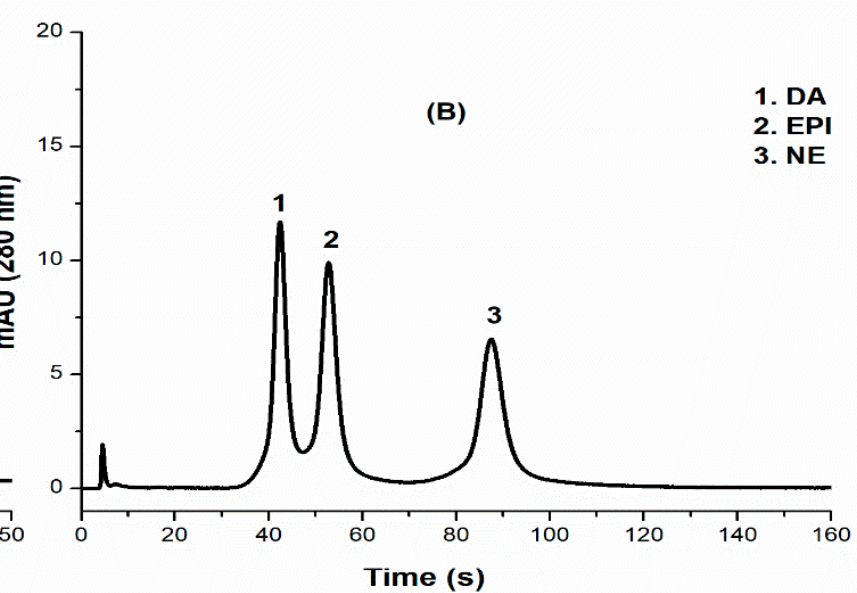

Time (s)

Figure 2. Chromatograms of mixture of $500 \mu \mathrm{M}$ each of DA, EPI, and NE. Mobile phase: ACN: $10 \mathrm{mM}$ ammonium formate pH 3 (85:15) (A) Poro-shell Z-HILIC $(2.1 \times 50 \mathrm{~mm} 2.7 \mu \mathrm{m})$; (B) fully porous Z-HILIC $(2.1 \times 50 \mathrm{~mm} 3.5 \mu \mathrm{m})$, and (C) fully porous Z-cHILIC $(2.1 \times 50 \mathrm{~mm} 3 \mu \mathrm{m}), 1.5 \mathrm{~mL} / \mathrm{min}$ flow rate, $1 \mu \mathrm{L}$ injection volume, at $280 \mathrm{~nm} \mathrm{UV}$ detection, and $23^{\circ} \mathrm{C}$.

The present study confirmed that the core-shell column provided superior performance over the fully porous columns in terms of efficiency and speed. The column efficiency is indicated as the number of theoretical plates $(\mathrm{N})$ per column, and the RSD (\%) values are reported in Table 1 . Table 1 indicates that the core-shell Z-HILIC column provided an almost twofold increase in efficiency in comparison to the two fully porous columns. The separation time was reduced by approximately $60 \%$ using the core-shell column (Figure 3).

Table 1. The number of theoretical plates (efficiency) per $m$ and RSD (\%) for CAs using different columns.

\begin{tabular}{llll}
\hline HILIC Columns & Analyte & N/m & RSD (\%) \\
\hline Poro-Shell Z-HILIC & DA & 49,040 & 0.98 \\
& EPI & 43,132 & 0.91 \\
& NE & 44,172 & 1.86 \\
\hline Fully Porous Z-cHILIC & DA & 23,019 & 0.72 \\
& EPI & 23,887 & 1.04 \\
& NE & 31,247 & 1.36 \\
\hline Fully Porous Z-HILIC & DA & 18,395 & 0.69 \\
& EPI & 16,973 & 2.01 \\
& NE & 22,598 & 2.27 \\
\hline
\end{tabular}



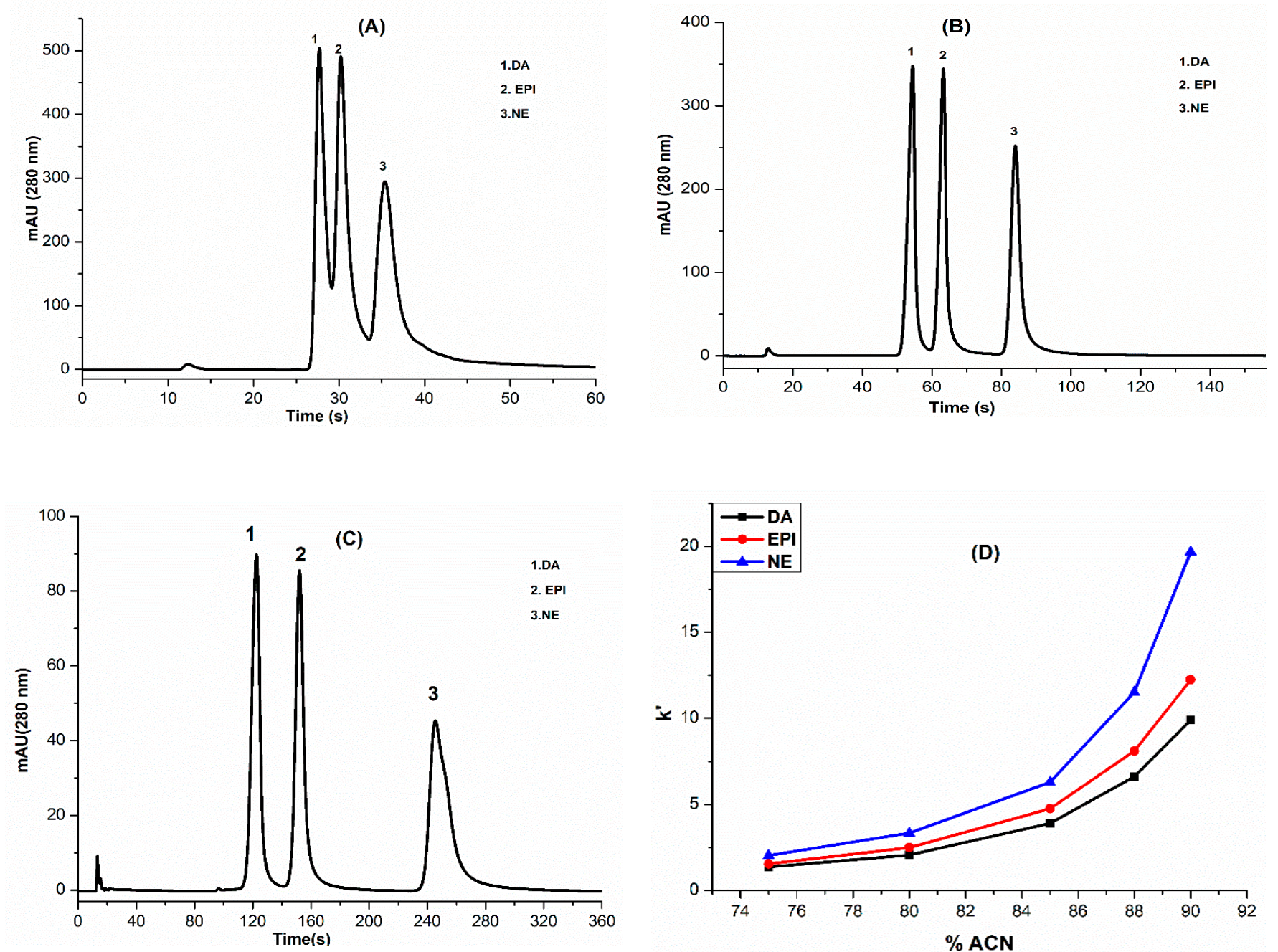

Figure 3. The effect of the concentration of $\mathrm{ACN}$ on the retention time of a mixture of $500 \mu \mathrm{M}$ each of 1 . DA, 2. EPI, and 3. NE. Mobile phase: ACN: 10 mM ammonium formate pH 3 (A) 75:25, (B) 85:15, (C) 90:10, (D) a plot of \% ACN versus k'. Column: Poro-shell Z-HILIC $(2.1 \times 50 \mathrm{~mm}, 2.7 \mu \mathrm{m}), 0.5 \mathrm{~mL} / \mathrm{min}$ flow rate, $5 \mu \mathrm{L}$ injection volume, at $280 \mathrm{~nm} \mathrm{UV}$ detection, and $23{ }^{\circ} \mathrm{C}$.

Selectivity $(\alpha)$ is another important factor that indicates the ability of the stationary phase to discriminate between analytes. $\alpha$ values were calculated between DA and EPI, and EPI and NE for each column (Table 2, Figure 2). The core-shell Z-HILIC column provided the best $\alpha$ value between DA and EPI at 1.3, while the Z-cHILIC provided the highest $\alpha$ value between EPI and NE at 1.84. Selectivity $(\alpha)$ values greater than 1 indicate that the three columns provided sufficient selectivity for the separation of CAs [58]. However, as the core-shell Z-HILIC column displayed higher efficiency and rapid separation, it was selected for all subsequent experiments. 
Table 2. Selectivity ( $\alpha$ ) values and RSD (\%) for CAs using different columns.

\begin{tabular}{llll}
\hline HILIC Columns & Analyte & $\alpha$ & RSD (\%) \\
\hline \multirow{2}{*}{ Poro-Shell Z-HILIC } & DA\& EPI & 1.30 & 0.572 \\
& EPI\& NE & 1.39 & 0.187 \\
\hline \multirow{2}{*}{ Fully Porous Z-cHILIC } & DA\& EPI & 1.22 & 0.417 \\
& EPI\& NE & 1.84 & 0.132 \\
\hline \multirow{2}{*}{ Fully Porous Z-HILIC } & DA\& EPI & 1.26 & 0.231 \\
& EPI\& NE & 1.71 & 0.214 \\
\hline
\end{tabular}

\subsection{Optimization of HILIC Separation Conditions}

The chromatographic separation of the selected biomarker CAs using the core-shell Z-HILIC column was initially performed at a flow rate of $0.5 \mathrm{~mL} / \mathrm{min}$ and UV detection at $280 \mathrm{~nm}$ and was optimized in terms of the mobile phase composition, buffer $\mathrm{pH}$, and concentration. Different mobile phase compositions were tested with varying percentages of ACN in $10 \mathrm{mM}$ ammonium formate buffer, as illustrated in Figure 3. A higher concentration of $\mathrm{ACN}$ in the mobile phase increase the retention times (Figure 3), as the polar analytes have a higher degree of partitioning in the thin water-enriched layer on the stationary phase [32].

Furthermore, it is important to highlight that, as the concentration of the organic solvent is increased, the $\mathrm{pH}$ of the mobile phase also increases. The measured $\mathrm{pH}$ in the presence of high organic solvent content $\left({ }_{w}^{\mathrm{s}} \mathrm{pH}\right)$ differed considerably from the actual $\mathrm{pH}$ measured on water $\left({ }_{w}^{w} \mathrm{pH}\right)$ using the $\mathrm{pH}$ meter calibrated with aqueous buffers $[32,59,60]$. This can potentially aid the deprotonation of the silanol group and increase the secondary interaction between the analyte and the silanol group, which would cause peak distortion and tailing [32,59].

Also, Figure S1 demonstrates the major effect of buffer $\mathrm{pH}$ on the peak shapes and peak intensities for the CAs. Increasing the $\mathrm{pH}$ from 3 to 5 caused peak broadening and tailing, and the peak heights were reduced by $18 \%$ for DA, 33\% for EPI, and $31 \%$ for NE. Similar findings were reported by Abhinav et al. for the separation of CAs using HILIC [32]. It is worth noting that $C A s$ are very reactive molecules, and they are kept in vesicles with acidic media in the brain as they can be easily degraded to their corresponding o-quinones forms in an alkaline environment [4]. Therefore, developing a separation method with a suitable $\mathrm{pH}$ value requires careful attention with CAs.

In addition, as the concentration of the ammonium formate buffer at $\mathrm{pH} 3$ increased from 10 to $20 \mathrm{mM}$, the retention times of the analytes decreased slightly, and the peaks became sharper [33]. The relationship between the inverse of buffer concentration and the retention time of the analytes can shed light on the mechanism involved in the separation. A linear plot would indicate ion exchange retention between the analytes and the stationary phase $[32,61]$. However, a slightly curved line plot indicates the presence of other mechanisms, such as HILIC partitioning and electrostatic interactions [32]. To obtain a rapid HILIC separation in less than $60 \mathrm{~s}$, faster flow rates were examined, and $1.5 \mathrm{~mL} / \mathrm{min}$ with a corresponding backpressure of 360 bar was chosen, as illustrated in Figure S2.

\subsection{Optimization of Detection Potential for $L C-E C D$}

The influence of the detection potential on the oxidation of the CAs was investigated in the range of +1.0 to $+1.7 \mathrm{~V}$ using amperometric detection. Figure 4 shows the hydrodynamic voltammograms of the CAs under the optimum separation conditions with the maximum oxidation currents occurring at $+1.3 \mathrm{~V}$. 


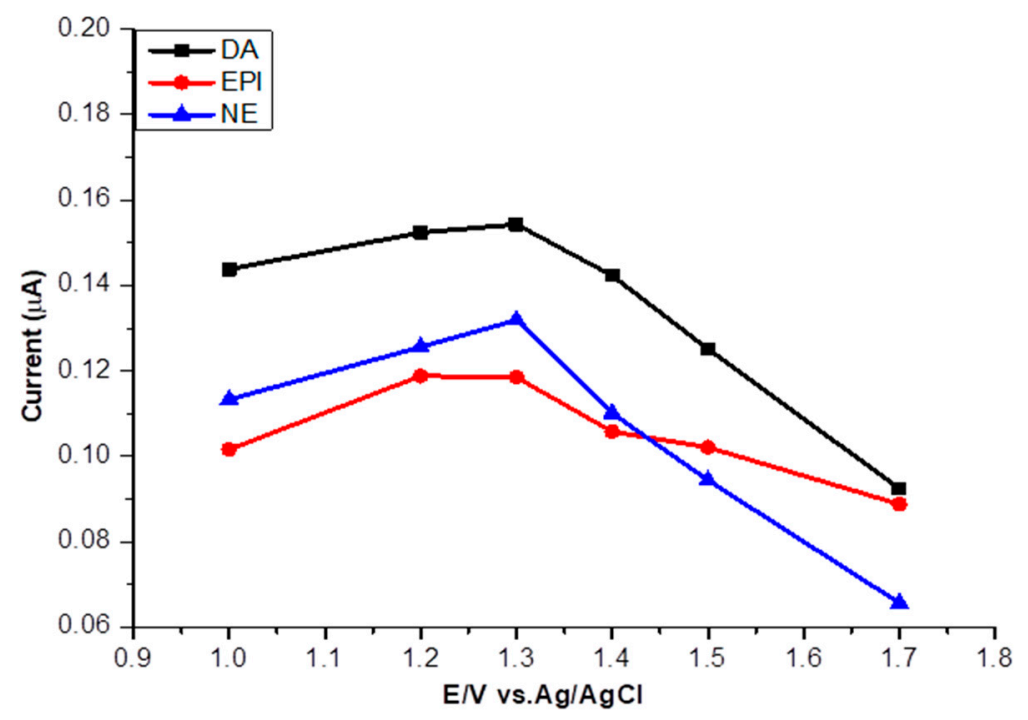

Figure 4. Plot of the effect of applied potential (E) versus current $(\mu \mathrm{A})$ for a mixture of $25 \mu \mathrm{M}$ each of DA, EPI, and NE at the BDD electrode vs. Pd/H . Mobile phase: 85:15, ACN: $10 \mathrm{mM}$ ammonium formate $\mathrm{pH}$ 3. Column: Poro-shell Z-HILIC $(2.1 \times 50 \mathrm{~mm}, 2.7 \mu \mathrm{m}), 1.5 \mathrm{~mL} / \mathrm{min}$ flow rate, $5 \mu \mathrm{L}$ injection volume, at $23^{\circ} \mathrm{C}$.

\subsection{Method Validation}

Linear calibration curves were obtained by the injection of a mixture of CAs with six different concentrations under the optimal separation conditions, initially with LC-UV (Table S1) and then with LC-BDD. The linear calibration range $(0.1-25 \mu \mathrm{M})$, regression equation, correlation coefficients, and LODs are presented in Table 3 for LC-BDD. Linear regression analysis was performed by plotting the peak areas versus concentrations with a correlation coefficient $\left(R^{2}\right)$ of more than 0.99 . The linearity of the three CAs was evaluated by triplicate injection of different concentrations of the standard mixtures.

The LODs (calculated at a S/N of 3) were $40 \mathrm{nM}$ for DA and $50 \mathrm{nM}$ for both EPI and NE with ECD. The LODs of CAs detected by the BDD electrode were lower than those obtained by UV, indicating the higher sensitivity achievable with the BDD electrode. The LODs reported in the present work were lower than those previously reported methods using the capillary electrophoresis (CE) chemiluminescence (CL) method [62], and using a magnetic molecularly imprinted polymer (MMIP) for the sorbent extraction and CE analysis [63].

However, the LODs of CAs using LC-MS [64] and LC-fluorescence detection [29] were lower than the present LODs, shown in Table 4. The nanomolar detection achievable with LC-BDD indicates its suitability in providing early diagnosis of TBI and cancer types previously stated. Repeatability and intermediate precision (intra- and inter-assay) were calculated as RSD\%. The intra-day and inter-day precision levels based on retention time were in the range of $0.35-0.42 \%$ and $0.4-0.65 \%$, respectively. This indicates good method repeatability, further confirming the applicability of this method for analysis of CAs (Table 5).

Table 3. The linear regression parameters of the calibration curves and LODs for the CA compounds.

\begin{tabular}{cccccc}
\hline Analyte & $\begin{array}{c}\text { Linear Range } \\
(\mu \mathrm{M})\end{array}$ & $\begin{array}{c}\text { Linear Regression } \\
\text { Equation }\end{array}$ & $\begin{array}{c}\text { Correlation } \\
\text { Coefficient }\left(\boldsymbol{R}^{2}\right)\end{array}$ & $\begin{array}{c}\text { LOD }^{\mathbf{a}} \\
\text { HPLC-ECD (nM) }\end{array}$ & $\begin{array}{c}\text { LOD }^{\mathbf{b}} \text { HPLC-UV } \\
(\boldsymbol{\mu M})\end{array}$ \\
\hline DA & $0.1-25$ & $\mathrm{y}=6 \times 10^{-8} \mathrm{C}-4 \times 10^{-9}$ & 0.994 & 40 & 0.5 \\
EPI & $0.1-25$ & $\mathrm{y}=5 \times 10^{-8} \mathrm{C}-3 \times 10^{-9}$ & 0.993 & 50 & 0.7 \\
NE & $0.1-25$ & $\mathrm{y}=4 \times 10^{-8} \mathrm{C}-4 \times 10^{-9}$ & 0.995 & 50 & 1 \\
\hline
\end{tabular}

${ }^{\mathrm{a}} \mathrm{LOD}(\mathrm{S} / \mathrm{N}=3)$ at $+1.3 \mathrm{~V} \cdot{ }^{\mathrm{b}} \mathrm{LOD}(\mathrm{S} / \mathrm{N}=3)$ at $280 \mathrm{~nm}$. 
Table 4. Comparison between the LOD values of CAs in the present work with those reported in the literature.

\begin{tabular}{|c|c|c|c|c|}
\hline Technique & Analytes & Separation Time & LOD & Ref. \\
\hline \multirow{3}{*}{ CE-CL } & DA & & $69 \mathrm{nM}$ & \multirow{3}{*}[62]{} \\
\hline & EPI & $6 \mathrm{~min}$ & 79 nM & \\
\hline & $\mathrm{NE}$ & & $100 \mathrm{nM}$ & \\
\hline \multirow{3}{*}{ MMIP-CE } & DA & \multirow{3}{*}{$8 \mathrm{~min}$} & $60 \mathrm{nM}$ & \multirow{3}{*}[63]{} \\
\hline & EPI & & $60 \mathrm{nM}$ & \\
\hline & $\mathrm{NE}$ & & $50 \mathrm{nM}$ & \\
\hline \multirow{3}{*}{ HPLC- fluorescence detection } & $\mathrm{DA}$ & \multirow{3}{*}{$40 \mathrm{~min}$} & $0.1 \mathrm{nM}$ & \multirow{3}{*}{ [29] } \\
\hline & EPI & & $0.4 \mathrm{nM}$ & \\
\hline & NE & & $0.4 \mathrm{nM}$ & \\
\hline \multirow{3}{*}{$\begin{array}{l}\text { RP-Amperometric detection } \\
\text { (BDD electrode) }\end{array}$} & DA & \multirow{3}{*}{$9 \mathrm{~min}$} & $4 \times 10^{-3} \mu \mathrm{g} / \mathrm{mL}(26 \mathrm{nM})$ & \multirow{3}{*}[65]{} \\
\hline & EPI & & $2 \times 10^{-3} \mu \mathrm{g} / \mathrm{mL}(11 \mathrm{nM})$ & \\
\hline & $\mathrm{NE}$ & & $4 \times 10^{-3} \mu \mathrm{g} / \mathrm{mL}(23 \mathrm{nM})$ & \\
\hline \multirow{3}{*}{ HPLC-MS-MS } & $\mathrm{DA}$ & \multirow{3}{*}{$6 \mathrm{~min}$} & $5 \mathrm{nM}$ & \multirow{3}{*}[64]{} \\
\hline & EPI & & $10 \mathrm{nM}$ & \\
\hline & $\mathrm{NE}$ & & $10 \mathrm{nM}$ & \\
\hline \multirow{3}{*}{$\begin{array}{l}\text { HILIC- Amperometric detection } \\
\text { (BDD electrode) }\end{array}$} & DA & \multirow{3}{*}{ less than $1 \mathrm{~min}$} & $40 \mathrm{nM}\left(7.5 \times 10^{-3} \mu \mathrm{g} / \mathrm{mL}\right)$ & \multirow{3}{*}{ This work } \\
\hline & EPI & & $50 \mathrm{nM}\left(10.6 \times 10^{-3} \mu \mathrm{g} / \mathrm{mL}\right)$ & \\
\hline & $\mathrm{NE}$ & & $50 \mathrm{nM}\left(10.2 \times 10^{-3} \mu \mathrm{g} / \mathrm{mL}\right)$ & \\
\hline
\end{tabular}

Table 5. The RSD (\%) Intra-day and inter-day data for CAs in LC-ECD.

\begin{tabular}{ccc}
\hline Analyte & RSD $^{\mathbf{a}} \mathbf{( \% )}$ Intra-Day & RSD $^{\mathbf{b}}$ (\%) Inter-Day \\
\hline DA & 0.42 & 0.65 \\
EPI & 0.35 & 0.40 \\
NE & 0.36 & 0.49
\end{tabular}

a RSD (\%) Intra-day values calculated from three measurements within one experiment for the retention time at $25 \mu \mathrm{M}$ of each standard. ${ }^{\mathrm{b}} \mathrm{RSD}(\%)$ Inter-day values calculated from three measurements within three different days for the retention time at $25 \mu \mathrm{M}$ of each standard.

\subsection{Urine Sample Analysis}

The applicability of the method was examined by evaluating its use in determining the concentrations of the three selected CAs in urine samples using the optimal LC-BDD method following PBA SPE [66-69]. In this study, PBA SPE, as described by Abhinav et al. [32], was used for urine sample pretreatment using the elution solvent under acidic conditions with $80 \%$ ACN making it a suitable and efficient step prior to HILIC separation. The recovery results obtained for each analyte after spiking urine samples at three different CAs concentration levels are shown in Table 6. RSD expresses the variation of peak areas for each analyte $(n=6$ each). The utilized SPE method provided good recovery values ranging from $90 \%$ to $94 \%$. These finding are in agreement with previously reported values [32].

Table 6. Recovery results obtained for CAs after spiking human urine samples at different DA, EPI, and NE concentration levels.

\begin{tabular}{|c|c|c|c|c|c|}
\hline Analytes & $\begin{array}{c}\text { Concentration (nM) in } \\
\text { Unspiked Urine }\end{array}$ & $\begin{array}{l}\text { Concentration } \\
\text { (nM) Added }\end{array}$ & $\begin{array}{l}\text { Concentration } \\
\text { (nM) Found }\end{array}$ & Recovery \% & RSD \% \\
\hline \multirow{3}{*}{ DA } & \multirow{3}{*}{1440} & 600 & 1990 & 91.6 & 4.6 \\
\hline & & 1500 & 2800 & 93 & 2.7 \\
\hline & & 3000 & 4170 & 90.9 & 2.3 \\
\hline \multirow{3}{*}{ EPI } & \multirow{3}{*}{$\mathrm{ND}^{\mathrm{a}}$} & 250 & 231 & 92.4 & 2.3 \\
\hline & & 500 & 471 & 94 & 6 \\
\hline & & 1000 & 915 & 91.5 & 4 \\
\hline \multirow{3}{*}{$\mathrm{NE}$} & \multirow{3}{*}{112} & 400 & 473 & 90.3 & 1.4 \\
\hline & & 800 & 840 & 91 & 2.7 \\
\hline & & 1600 & 1550 & 90 & 2.4 \\
\hline
\end{tabular}


DA and NE were successfully quantified in the unspiked urine samples, and the calculated concentrations are presented in Table 7. EPI was not quantifiable in the urine samples. This might be due to the low concentration of EPI, below the detection limit, which was also reported by $\mathrm{Xu}$ et al. [62]. The expected ranges of urinary CAs over a $24 \mathrm{~h}$ period were 65-400 $\mu \mathrm{g} / \mathrm{L}$ DA, 0-20 $\mu \mathrm{g} / \mathrm{L}$ EPI, and 15-80 $\mu \mathrm{g} / \mathrm{L}$ NE [70]. The calculated values of DA and NE in urine samples were in the normal range of their concentration in urine. Figure 5 shows a representative chromatogram of a urine sample spiked with a mixture of CAs $(3 \mu \mathrm{M})$.

Table 7. The concentration of CAs in the unspiked urine samples $(n=6)$.

\begin{tabular}{cccc}
\hline Sample & DA $(\mathbf{n M}) \pm$ SD & EPI $(\mathbf{n M}) \pm$ SD & NE (nM) \pm SD \\
\hline 1 & $1440 \pm 1.44$ & ND $^{a}$ & $112 \pm 1.67$ \\
\hline 2 & $1793 \pm 1.34$ & ND $^{a}$ & $158 \pm 2.67$ \\
\hline
\end{tabular}

$\mathrm{ND}^{\mathrm{a}}$ Not detected.

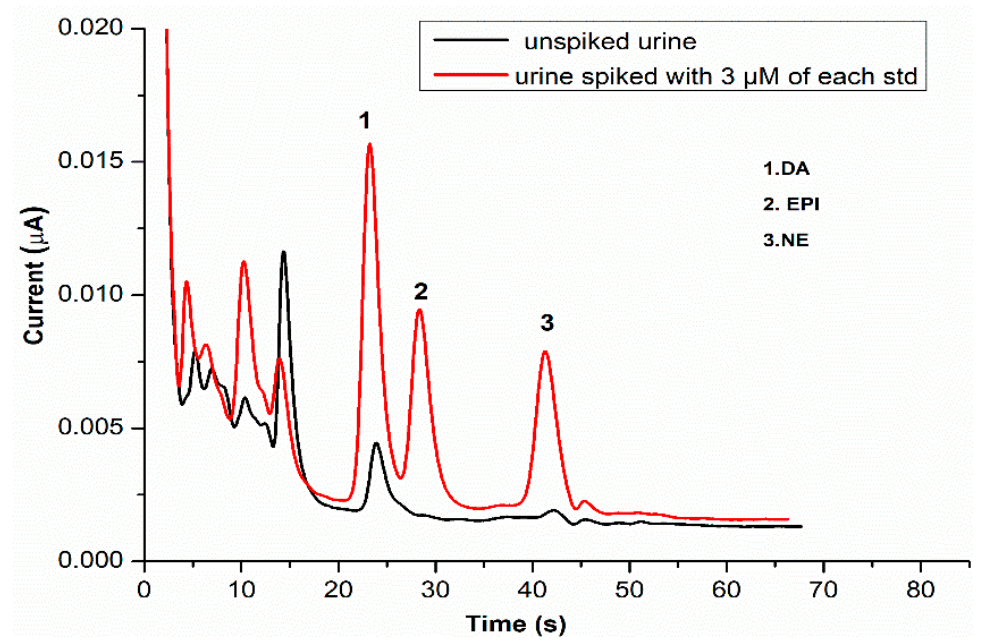

Figure 5. The HPLC-ECD BDD chromatogram of a urine sample, the black line is unspiked urine, and the red line is spiked urine with $3 \mu \mathrm{M}$ each of DA, EPI, and NE. Mobile phase: 15: 85, $10 \mathrm{mM}$ ammonium formate $\mathrm{pH}$ 3: ACN. Column: Poro-shell z-HILIC $(2.1 \times 50 \mathrm{~mm}, 2.7 \mu \mathrm{m}), 1.5 \mathrm{~mL} / \mathrm{min}$ flow rate, $5 \mu \mathrm{L}$ injection volume, at $23^{\circ} \mathrm{C}$. detector: oxidation potential: $+1.3 \mathrm{~V}$ on the BDD electrode vs. $\mathrm{Pd} / \mathrm{H}_{2}$.

\section{Conclusions}

An efficient, rapid, and sensitive separation method for dopamine (DA), epinephrine (EPI), and norepinephrine (NE) has been optimized, combining the superior performance of a core-shell Z-HILIC column coupled to nanomolar ECD at a BDD electrode. The core-shell Z-HILIC column provided higher efficiency with separation in less than $60 \mathrm{~s}$ in comparison to the fully porous Z-HILIC stationary phases. The proposed method represents sufficient precision and linearity to enable the rapid separation of DA, EPI, and NE with sensitive detection at a downstream BDD electrode.

The applicability of the developed method was evaluated by determining the CA levels in urine samples following SPE based on PBA. The concentrations of DA and NE in unspiked urine samples were determined, and their values were in the expected range for these CAs in urine. This rapid LC-BDD method could be effectively applied for the screening of CAs overproduction in urine samples for patients with TBI, pheochromocytoma, and paraganglioma [12,71,72].

Supplementary Materials: The following are available online at https: / www.mdpi.com/article/ 10.3390/separations8080124/s1, Figure S1: Effect of the mobile phase $\mathrm{pH}$ on the retention time of a mixture of $500 \mu \mathrm{M}$ each of DA, EPI, and NE. Mobile phase: 15:85, ACN: $10 \mathrm{mM}$ ammonium 
formate $\mathrm{pH} 3$ (A) and $10 \mathrm{mM}$ ammonium acetate $\mathrm{pH} 5$ (B) Column: Poro-shell Z-HILIC $(2.1 \times 50 \mathrm{~mm}$, $2.7 \mu \mathrm{m}$ ), flow rate: $0.5 \mathrm{~mL} / \mathrm{min}$, injection volume: $5 \mu \mathrm{L}$, UV detection: $280 \mathrm{~nm}$, and temperature $23^{\circ} \mathrm{C}$. Figure S2: Effect of the mobile phase flow rate on the retention time of a mixture of $500 \mu \mathrm{M}$ each of DA, EPI, and NE. Mobile phase: ACN: 10 mM ammonium formate pH 3 (85:15). Column: Poro-shell Z-HILIC $(2.1 \times 50 \mathrm{~mm}, 2.7 \mu \mathrm{m})$, injection volume: $1 \mu \mathrm{L}$, UV detection: $280 \mathrm{~nm}$, temperature $23^{\circ} \mathrm{C}$ flow rate: $1.5 \mathrm{~mL} / \mathrm{min}(\mathrm{A}), 1 \mathrm{~mL} / \mathrm{min}(\mathrm{B}), 0.5 \mathrm{~mL} / \mathrm{min}(\mathrm{C})$. Table $\mathrm{S} 1$ : Linear regression parameters of the calibration curves and precision data with HPLC-UV at $280 \mathrm{~nm}$.

Author Contributions: Conceptualization, M.A. and J.D.G.; methodology, M.A.; software, M.A.; validation, M.A. and H.A.; formal analysis, M.A.; investigation, M.A. and H.A.; resources, M.A. and H.A.; data curation, M.A. and P.E.H.; writing—original draft preparation, M.A.; writing-review and editing, M.A., P.E.H., A.M.H. and J.D.G.; visualization, M.A. and A.M.H.; supervision, J.D.G.; project administration, J.D.G.; funding acquisition, J.D.G. and M.A. All authors have read and agreed to the published version of the manuscript.

Funding: This research was funded by Science Foundation Ireland, grant number (08/SRC/B1412), and the Saudi Ministry of Education and Cultural Bureau, Dublin, Ireland.

Institutional Review Board Statement: Ethical review and approval were waived for this study, due to it being non-medical research.

Informed Consent Statement: Not applicable.

Acknowledgments: JDG thanks the Science Foundation Ireland (08/SRC/B1412) for previous research funding of the Irish Separation Science Cluster (ISSC) under the Strategic Research Cluster Programme. MA thanks the Saudi Ministry of Education and Cultural Bureau, Dublin, Ireland, for research funding.

Conflicts of Interest: There are no conflict to declare.

\section{References}

1. Goldstein, D.S.; Eisenhofer, G.; Kopin, I.J. Sources and Significance of Plasma Levels of Catechols and Their Metabolites in Humans. J. Pharmacol. Exp. Ther. 2003, 305, 800. [CrossRef] [PubMed]

2. Laverty, R. Catecholamines: Role in Health and Disease. Drugs 1978, 16, 418-440. [CrossRef] [PubMed]

3. Focke, P.J.; Wang, X.; Larsson, H.P. Neurotransmitter transporters: Structure meets function. Structure 2013, 21, 694-705. [CrossRef] [PubMed]

4. Meiser, J.; Weindl, D.; Hiller, K. Complexity of dopamine metabolism. Cell Commun. Signal. 2013, 11, 34. [CrossRef] [PubMed]

5. Pan, X.; Kaminga, A.C.; Jia, P.; Wen, S.W.; Acheampong, K.; Liu, A. Catecholamines in Alzheimer's Disease: A Systematic Review and Meta-Analysis. Front. Aging Neurosci. 2020, 12, 184. [CrossRef]

6. Kordower, J.H.; Olanow, C.W.; Dodiya, H.B.; Chu, Y.; Beach, T.G.; Adler, C.H.; Halliday, G.M.; Bartus, R.T. Disease duration and the integrity of the nigrostriatal system in Parkinson's disease. Brain 2013, 136, 2419-2431. [CrossRef]

7. Olivares-Hernández, A.; Figuero-Pérez, L.; Cruz-Hernandez, J.J.; González Sarmiento, R.; Usategui-Martin, R.; Miramontes-González, J.P. Dopamine Receptors and the Kidney: An Overview of Health- and Pharmacological-Targeted Implications. Biomolecules 2021, 11, 254. [CrossRef]

8. Adameova, A.; Abdellatif, Y.; Dhalla, N.S. Role of the excessive amounts of circulating catecholamines and glucocorticoids in stress-induced heart disease. Can. J. Physiol. Pharmacol. 2009, 87, 493-514. [CrossRef]

9. Fung, M.M.; Viveros, O.H.; O'Connor, D.T. Diseases of the adrenal medulla. Acta Physiol. 2008, 192, 325-335. [CrossRef]

10. Barron, J. Phaeochromocytoma: Diagnostic challenges for biochemical screening and diagnosis. J. Clin. Pathol. 2010, 63, 669-674. [CrossRef]

11. Rizoli, S.B.; Jaja, B.N.R.; Di Battista, A.P.; Rhind, S.G.; Neto, A.C.; da Costa, L.; Inaba, K.; da Luz, L.T.; Nascimento, B.; Perez, A.; et al. Catecholamines as outcome markers in isolated traumatic brain injury: The COMA-TBI study. Crit. Care 2017, 21, 37. [CrossRef]

12. Hamill, R.W.; Woolf, P.D.; McDonald, J.V.; Lee, L.A.; Kelly, M. Catecholamines predict outcome in traumatic brain injury. Ann. Neurol. 1987, 21, 438-443. [CrossRef]

13. Clifton, G.L.; Ziegler, M.G.; Grossman, R.G. Circulating catecholamines and sympathetic activity after head injury. Neurosurgery 1981, 8, 10-14. [CrossRef]

14. Trifonova, O.P.; Maslov, D.L.; Balashova, E.E.; Urazgildeeva, G.R.; Abaimov, D.A.; Fedotova, E.Y.; Poleschuk, V.V.; Illarioshkin, S.N.; Lokhov, P.G. Parkinson's Disease: Available Clinical and Promising Omics Tests for Diagnostics, Disease Risk Assessment, and Pharmacotherapy Personalization. Diagnostics 2020, 10, 339. [CrossRef]

15. Sawada, H.; Oeda, T.; Yamamoto, K. Catecholamines and Neurodegeneration in Parkinson's Disease-From Diagnostic Marker to Aggregations of $\alpha$-Synuclein. Diagnostics 2013, 3, 210-221. [CrossRef] [PubMed] 
16. Goldstein, D.S.; Holmes, C.; Sharabi, Y. Cerebrospinal fluid biomarkers of central catecholamine deficiency in Parkinson's disease and other synucleinopathies. Brain 2012, 135, 1900-1913. [CrossRef] [PubMed]

17. Vermeiren, Y.; Hirschberg, Y.; Mertens, I.; De Deyn, P.P. Biofluid Markers for Prodromal Parkinson's Disease: Evidence from a Catecholaminergic Perspective. Front. Neurol. 2020, 11, 595. [CrossRef] [PubMed]

18. Kim, A.R.; Nodel, M.R.; Pavlenko, T.A.; Chesnokova, N.B.; Yakhno, N.N.; Ugrumov, M.V. Tear Fluid Catecholamines as Biomarkers of the Parkinson's Disease: A Clinical and Experimental Study. Acta Nat. 2019, 11, 99-103. [CrossRef] [PubMed]

19. Song, J.; Kim, J. Degeneration of Dopaminergic Neurons due to Metabolic Alterations and Parkinson's Disease. Front. Aging Neurosci. 2016, 8, 65. [CrossRef] [PubMed]

20. Chekhonin, V.P.; Baklaushev, V.P.; Kogan, B.M.; Savchenko, E.A.; Lebedev, S.V.; Man’kovskaya, I.V.; Filatova, T.S.; Yusupova, I.U.; Dmitrieva, T.B. Catecholamines and their metabolites in the brain and urine of rats with experimental Parkinson's disease. Bull. Exp. Biol. Med. 2000, 130, 805-809.

21. van Faassen, M.; Bischoff, R.; Eijkelenkamp, K.; de Jong, W.H.A.; van der Ley, C.P.; Kema, I.P. In Matrix Derivatization Combined with LC-MS/MS Results in Ultrasensitive Quantification of Plasma Free Metanephrines and Catecholamines. Anal. Chem. 2020, 92, 9072-9078. [CrossRef]

22. Chung, H.; Tajiri, S.; Hyoguchi, M.; Koyanagi, R.; Shimura, A.; Takata, F.; Dohgu, S.; Matsui, T. Analysis of Catecholamine and Their Metabolites in Mice Brain by Liquid Chromatography-Mass Spectrometry Using Sulfonated Mixed-mode Copolymer Column. Anal. Sci. 2019, 35, 433-439. [CrossRef]

23. Peitzsch, M.; Pelzel, D.; Glöckner, S.; Prejbisz, A.; Fassnacht, M.; Beuschlein, F.; Januszewicz, A.; Siegert, G.; Eisenhofer, G. Simultaneous liquid chromatography tandem mass spectrometric determination of urinary free metanephrines and catecholamines, with comparisons of free and deconjugated metabolites. Clin. Chim. Acta 2013, 418, 50-58. [CrossRef] [PubMed]

24. Machida, M.; Sakaguchi, A.; Kamada, S.; Fujimoto, T.; Takechi, S.; Kakinoki, S.; Nomura, A. Simultaneous analysis of human plasma catecholamines by high-performance liquid chromatography with a reversed-phase triacontylsilyl silica column. J. Chromatogr. B Biomed. Sci. Appl. 2006, 830, 249-254. [CrossRef]

25. Kumarathasan, P.; Vincent, R. New approach to the simultaneous analysis of catecholamines and tyrosines in biological fluids. J. Chromatogr. A 2003, 987, 349-358. [CrossRef]

26. Ehrenström, F.; Johansson, P. A method for very rapid determinations of catechols using ion-pairing reverse phase HPLC with electrochemical detection: Effects of L-DOPA treatment on the catechol content in various rat brain structures. Life Sci. 1985, 36, 867-879. [CrossRef]

27. Speek, A.J.; Odink, J.; Schrijver, J.; Schreurs, W.H.P. High-performance liquid chromatographic determination of urinary free catecholamines with electrochemical detection after prepurification on immobilized boric acid. Clin. Chim. Acta 1983, 128, 103-113. [CrossRef]

28. Birbeck, J.A.; Mathews, T.A. Simultaneous Detection of Monoamine and Purine Molecules Using High-Performance Liquid Chromatography with a Boron-Doped Diamond Electrode. Anal. Chem. 2013, 85, 7398-7404. [CrossRef] [PubMed]

29. Huang, X.; Guo, X.-F.; Wang, H.; Zhang, H.-S. Analysis of catecholamines and related compounds in one whole metabolic pathway with high performance liquid chromatography based on derivatization. Arab. J. Chem 2019, 12, 1159-1167. [CrossRef]

30. Konieczna, L.; Roszkowska, A.; Niedźwiecki, M.; Bączek, T. Hydrophilic interaction chromatography combined with dispersive liquid-liquid microextraction as a preconcentration tool for the simultaneous determination of the panel of underivatized neurotransmitters in human urine samples. J. Chromatogr. A 2016, 1431, 111-121. [CrossRef]

31. Miękus, N.; Konieczna, L.; Kowiański, P.; Moryś, J.; Baczek, T. HILIC-MS Rat Brain Analysis, A New Approach for the Study of Ischemic Attack. Transl. Neurosci. 2017, 8, 70-75. [CrossRef]

32. Kumar, A.; Hart, J.P.; McCalley, D.V. Determination of catecholamines in urine using hydrophilic interaction chromatography with electrochemical detection. J. Chromatogr. A 2011, 1218, 3854-3861. [CrossRef] [PubMed]

33. McCalley, D.V. Study of the selectivity, retention mechanisms and performance of alternative silica-based stationary phases for separation of ionised solutes in hydrophilic interaction chromatography. J. Chromatogr. A 2010, 1217, 3408-3417. [CrossRef] [PubMed]

34. Kobayashi, H.; Ikegami, T.; Kimura, H.; Hara, T.; Tokuda, D.; Tanaka, N. Properties of monolithic silica columns for HPLC. Anal. Sci. 2006, 22, 491-501. [CrossRef]

35. Cabrera, K. Applications of silica-based monolithic HPLC columns. J. Sep. Sci 2004, 27, 843-852. [CrossRef] [PubMed]

36. Hayes, R.; Ahmed, A.; Edge, T.; Zhang, H. Core-shell particles: Preparation, fundamentals and applications in high performance liquid chromatography. J. Chromatogr. A 2014, 1357, 36-52. [CrossRef]

37. Gosetti, F. Benefits and Drawbacks of Fully Porous sub-2 $\mu \mathrm{m}$ and Core-Shell Particles. Comparative UHPLC Applications in Food, Environmental, Forensic, Biopharmaceutical and Natural Products Analyses. Curr. Chromatogr 2018, 5, 18-32. [CrossRef]

38. DeStefano, J.J.; Schuster, S.A.; Lawhorn, J.M.; Kirkland, J.J. Performance characteristics of new superficially porous particles. J. Chromatogr. A 2012, 1258, 76-83. [CrossRef]

39. Kirkland, J.J.; Schuster, S.A.; Johnson, W.L.; Boyes, B.E. Fused-core particle technology in high-performance liquid chromatography: An overview. J. Pharm. Anal. 2013, 3, 303-312. [CrossRef]

40. Wagner, B.M.; Schuster, S.A.; Boyes, B.E.; Kirkland, J.J. Superficially porous silica particles with wide pores for biomacromolecular separations. J. Chromatogr. A 2012, 1264, 22-30. [CrossRef] 
41. Langsi, V.K.; Ashu-Arrah, B.A.; Ward, N.; Glennon, J.D. Synthesis and characterisation of non-bonded 1.7 $\mu \mathrm{m}$ thin-shell (TS1.7$100 \mathrm{~nm}$ ) silica particles for the rapid separation and analysis of uric acid and creatinine in human urine by hydrophilic interaction chromatography. J. Chromatogr. A 2017, 1506, 37-44. [CrossRef]

42. Ruta, J.; Guillarme, D.; Rudaz, S.; Veuthey, J.-L. Comparison of columns packed with porous sub-2 $\mu$ m particles and superficially porous sub-3 $\mu \mathrm{m}$ particles for peptide analysis at ambient and high temperature. J. Sep. Sci. 2010, 33, 2465-2477. [CrossRef] [PubMed]

43. Barman, K.; Jasimuddin, S. Simultaneous electrochemical detection of dopamine and epinephrine in the presence of ascorbic acid and uric acid using a AgNPs-penicillamine-Au electrode. RSC Adv. 2016, 6, 99983-99988. [CrossRef]

44. Sarada, B.V.; Rao, T.N.; Tryk, D.A.; Fujishima, A. Electrochemical oxidation of histamine and serotonin at highly boron- doped diamond electrodes. Anal. Chem. 2000, 72, 1632-1638. [CrossRef] [PubMed]

45. Swain, G.M.; Anderson, A.B.; Angus, J.C. Applications of Diamond Thin Films in Electrochemistry. MRS Bull. 1998, 23, 56-60. [CrossRef]

46. Bouamrane, F.; Tadjeddine, A.; Butler, J.E.; Tenne, R.; Lévy-Clément, C. Electrochemical study of diamond thin films in neutral and basic solutions of nitrate. J. Electroanal. Chem. 1996, 405, 95-99. [CrossRef]

47. DeClements, R.; Swain, G.M. The formation and electrochemical activity of microporous diamond thin film electrodes in concentrated KOH. J. Electrochem. Soc. 1997, 144, 856-866. [CrossRef]

48. Rao, T.N.; Sarada, B.V.; Tryk, D.A.; Fujishima, A. Electroanalytical study of sulfa drugs at diamond electrodes and their determination by HPLC with amperometric detection. J. Electroanal. Chem. 2000, 491, 175-181. [CrossRef]

49. Terashima, C.; Rao, T.N.; Sarada, B.V.; Tryk, D.A.; Fujishima, A. Electrochemical Oxidation of Chlorophenols at a Boron-Doped Diamond Electrode and Their Determination by High-Performance Liquid Chromatography with Amperometric Detection. Anal. Chem. 2002, 74, 895-902. [CrossRef]

50. Ivandini, T.A.; Sato, R.; Makide, Y.; Fujishima, A.; Einaga, Y. Pt-implanted boron-doped diamond electrodes and the application for electrochemical detection of hydrogen peroxide. Diam. Relat. Mater. 2005, 14, 2133-2138. [CrossRef]

51. Hayes, P.E.; Luong, J.H.T.; Gilchrist, E.S.; Buzid, A.; Glennon, J.D. Profiling of phenolic flavorings using core-shell reversed-phase liquid chromatography with electrochemical detection at a boron-doped diamond electrode. J. Chromatogr. A 2020, 1612, 460649. [CrossRef] [PubMed]

52. Hawley, M.D.; Tatawawadi, S.V.; Piekarski, S.; Adams, R.N. Electrochemical Studies of the Oxidation Pathways of Catecholamines. J. Am. Chem. Soc. 1967, 89, 447-450. [CrossRef] [PubMed]

53. Sochr, J.; Švorc, L'.; Rievaj, M.; Bustin, D. Electrochemical determination of adrenaline in human urine using a boron-doped diamond film electrode. Diam. Relat. Mater. 2014, 43, 5-11. [CrossRef]

54. Wei, M.; Sun, L.-G.; Xie, Z.-Y.; Zhii, J.-F.; Fujishima, A.; Einaga, Y.; Fu, D.-G.; Wang, X.-M.; Gu, Z.-Z. Selective Determination of Dopamine on a Boron-Doped Diamond Electrode Modified with Gold Nanoparticle/Polyelectrolyte-coated Polystyrene Colloids. Adv. Funct. Mater. 2008, 18, 1414-1421. [CrossRef]

55. Brycht, M.; Baluchová, S.; Taylor, A.; Mortet, V.; Sedláková, S.; Klimša, L.; Kopeček, J.; Schwarzová-Pecková, K. Comparison of electrochemical performance of various boron-doped diamond electrodes: Dopamine sensing in biomimicking media used for cell cultivation. Bioelectrochemistry 2021, 137, 107646. [CrossRef]

56. Colleran, J.J.; Breslin, C.B. Simultaneous electrochemical detection of the catecholamines and ascorbic acid at PEDOT/S- $\beta-C D$ modified gold electrodes. J. Electroanal. Chem. 2012, 667, 30-37. [CrossRef]

57. Ferry, Y.; Leech, D. Amperometric Detection of Catecholamine Neurotransmitters Using Electrocatalytic Substrate Recycling at a Laccase Electrode. Electroanalysis 2005, 17, 113-119. [CrossRef]

58. Benická, E.; Krupcík, J.; Lehotay, J.; Sandra, P.; Armstrong, D.W. Selectivity Tuning in an HPLC Multicomponent Separation. J. Liq. Chromatogr. Relat. Technol. 2005, 28, 1453-1471. [CrossRef]

59. McCalley, D.V. Is hydrophilic interaction chromatography with silica columns a viable alternative to reversed-phase liquid chromatography for the analysis of ionisable compounds? J. Chromatogr. A 2007, 1171, 46-55. [CrossRef]

60. Alvarez-Segura, T.; Subirats, X.; Rosés, M. Retention-pH profiles of acids and bases in hydrophilic interaction liquid chromatography. Anal. Chim. Acta 2019, 1050, 176-184. [CrossRef]

61. Bicker, W.; Wu, J.; Yeman, H.; Albert, K.; Lindner, W. Retention and selectivity effects caused by bonding of a polar urea-type ligand to silica: A study on mixed-mode retention mechanisms and the pivotal role of solute-silanol interactions in the hydrophilic interaction chromatography elution mode. J. Chromatogr. A 2011, 1218, 882-895. [CrossRef] [PubMed]

62. Xu, X.; Zhang, H.; Shi, H.; Ma, C.; Cong, B.; Kang, W. Determination of three major catecholamines in human urine by capillary zone electrophoresis with chemiluminescence detection. Anal. Biochem. 2012, 427, 10-17. [CrossRef]

63. Bouri, M.; Lerma-García, M.J.; Salghi, R.; Zougagh, M.; Ríos, A. Selective extraction and determination of catecholamines in urine samples by using a dopamine magnetic molecularly imprinted polymer and capillary electrophoresis. Talanta 2012, 99, 897-903. [CrossRef] [PubMed]

64. Whiting, M.J. Simultaneous measurement of urinary metanephrines and catecholamines by liquid chromatography with tandem mass spectrometric detection. Ann. Clin. Biochem. 2009, 46, 129-136. [CrossRef]

65. Zhang, L.; Yang, J.-q.; Luo, Y.; Shang, J.-c.; Jiang, X.-h. Simultaneous determination of eleven compounds related to metabolism of bioamines in rat cortex and hippocampus by HPLC-ECD with boron-doped diamond working electrode. J. Pharm. Biomed. Anal. 2016, 118, 41-51. [CrossRef] 
66. Nikolajsen, R.P.H.; Hansen, Å.M. Analytical methods for determining urinary catecholamines in healthy subjects. Anal. Chim. Acta 2001, 449, 1-15. [CrossRef]

67. Thomas, D.H.; Taylor, J.D.; Barnaby, O.S.; Hage, D.S. Determination of free catecholamines in urine by tandem affinity/ion-pair chromatography and flow injection analysis. Clin. Chim. Acta 2008, 398, 63-69. [CrossRef]

68. Wu, A.H.; Gornet, T.G. Preparation of urine samples for liquid-chromatographic determination of catecholamines: Bonded-phase phenylboronic acid, cation-exchange resin, and alumina adsorbents compared. Clin. Chem. 1985, 31, 298-302. [CrossRef]

69. Bicker, J.; Fortuna, A.; Alves, G.; Falcão, A. Liquid chromatographic methods for the quantification of catecholamines and their metabolites in several biological samples-A review. Anal. Chim. Acta 2013, 768, 12-34. [CrossRef]

70. Chou, D. Clinical Guide to Laboratory Tests. JAMA 1984, 251, 2587-2588. [CrossRef]

71. Shen, Y.; Cheng, L. Biochemical Diagnosis of Pheochromocytoma and Paraganglioma. In Paraganglioma: A Multidisciplinary Approach; Mariani-Costantini, R., Ed.; Codon Publications: Brisbane, Australia, 2019.

72. Patel, D.; Phay, J.E.; Yen, T.W.F.; Dickson, P.V.; Wang, T.S.; Garcia, R.; Yang, A.D.; Solórzano, C.C.; Kim, L.T. Update on Pheochromocytoma and Paraganglioma from the SSO Endocrine/Head and Neck Disease-Site Work Group. Part 1 of 2 Advances in Pathogenesis and Diagnosis of Pheochromocytoma and Paraganglioma. Ann. Surg. Oncol. 2020, 27, $1329-1337$. [CrossRef] [PubMed] 